VICTORIA SEMENOVA (1)

Institute of Sociology FCTAS RAS Moscow

ELENA ROZHDESTVENSKAYA (1)

National Research University Higher School of Economics, Moscow

\title{
FLORIAN ZNANIECKI HERITAGE IN THE CONTEXT OF RUSSIAN DISCOURSE
}

\begin{abstract}
The article is devoted to the problem of the transmission of scientific knowledge in the context of globalization of qualitative paradigm. This has to do not only with language barriers but also with political and scientific contexts, in which research is embedded [Flick 2014]. Here we will try to touch upon some aspects of the process focusing on Russian specifics in receiving and interpreting F. Znaniecki's ideas and concepts. 1) How did the dominant normative model of society influence the professional attitudes and behavior towards "new" kind of sociological thinking? 2) How did "new" interact with the habitual system of knowledge and methodological orientations of scientific community? 3) How did internal differentiation influence on perception of new ideas? ("man of knowledge" type).

The article tries to follow this process in a chronological way in the frames of changing social and professional context of the country. The first part is devoted to late Soviet period; the second - to the first post-Soviet period of democratization and humanization in social knowledge field; and the last - to current situation of developing national specifics based on initial export
\end{abstract}

Prof. Ph.D. in Sociology, Institute of Sociology; e-mail: victoria-sem@yandex.rul; https://orcid.org/0000-0002-0887-5106

Dr. in Sociology, Professor; e-mail: erozhdestvenskaya@hse.ru; https://orcid.org/0000-0001-6874-2404 
of methodological concept of "humanistic coefficient" (F. Znaniecki) along with the wide flow of European and American qualitative-interpretive tradition.

Keywords: Florian Znaniecki, knowledge globalization, interpretative sociology, professional sociological community, empirical research, Russian context

\section{INTRODUCTION}

Florian Witold Znaniecki is undoubtedly one of the greatest sociologists of the $20^{\text {th }}$ century, who realized himself in different cultural milieus - from agricultural Poland to Western Europe and the United States - and who has contributed much to various spheres of social knowledge - from philosophy to social psychology. The reconstruction of the significance of his heritage for sociology could be traced in various dimensions. It could be done as historical reconstruction, by comparing his views with sociological thought of his time. Then, it is possible to trace how F. Znaniecki's views and ideas were received by different "host" audiences during the subsequent development of sociological thinking and in different socio-cultural contexts, where and when F. Znaniecki's ideas were seen from different angles. In this small-scale essay, we will try to touch upon some of such aspects, focusing on Russian specifics ${ }^{1}$ in receiving and interpreting F. Znaniecki's ideas.

We would like to start from some meaningful point, in which, in our view, the retrospective and the perspective focuses intersect. This point could be named as a socially optimistic or romantic moment. The starting period of the qualitative method's "era" in sociology must have been obviously like that, optimistic, when positive expectations and hope for social reform performed on the basis of interpretative sociology, were seen as much closer to social reality then positivism that dominated in that time.

This remark on Znaniecki romanticism was emphasized by Heinz Abels, who connected the origin of his ideas with European romanticism of the early

1 Since the 2000s alone, about 90 publications published in Russia related to the name of F. Znaniecki and his legacy, which can be found on the website of one of the largest electronic scientific libraries of Russia https://elibrary.ru/ . The main circle of topics linked to the name of F. Znaniecki includes: Chicago school in sociology; man of knowledge; agency; modernization process of the Polish peasantry; the phenomenon of migration and evolution of the transnational migration system; social adaptation of migrants; the quality of the urban space; ethnicity in the context of understanding sociology; the interpretation of social action; professional career; values; oral history; modeling of the past; cultural memory; autobiography. 
$19^{\text {th }}$ century [Abels 1998]. Herewith we should point that H. Abels understood romanticism as an innovative movement of intellectuals against traditionalism, as an opposition to the objectivist concept of Enlightenment, as well as a new understanding of reality introduced along by the romanticists, i.e. not as a single whole, but as plurality of realities, each of them being meaningful and valorized. Ideological disputes between the romanticists and the pro-Enlightenment rationalists included a scenario, where traditional values were in the process of destruction and the task for creating the new meanings was on agenda. Let us remark here what Abels noted in the context of $\mathrm{F}$. Znaniecki's ideas origin: it is a romantic aspiration to understand the reality as temporality, as an ongoing process; it is also a rejection of objectification, what gives the entrance to the subsequent path to phenomenology and understanding as the main intentions of qualitative sociology [Abels 1998]. Choosing the intuitive "unpacking" of the object and a creative approach towards the selection or even invention of the research method brings us closer to the origin of the phenomenon in a certain context. That became the essential grounds for F. Znaniecki's activities during both Polish periods in his biography as well as during his Chicago School period. The most famous research made by the Chicago School was the study of W. Thomas and F. Znaniecki The Polish Peasant in Europe and America, 1918-1920, which, in a way, labeled the whole field of qualitative studies. As well known, the research was focused on analyzing hundreds of biographical documents, including letters, diaries, and memoirs of Polish peasant immigrants in Chicago. The authors examined this huge scope of empirical data from a definite focus, i.e. as evidence for disruption with the established social pattern of Polish peasant community and as a need for mastering a new cultural, social, and industrial context in a receiving country. Letters written to the relatives left behind became documents about adaptation and testimonies of nostalgia for the lost social world. However, it was not the new lifestyle and quality of life in America that loosened previously strong family ties and morals of former Polish peasants. W. Thomas and F. Znaniecki connected the weakening of these ties directly with the emergence of new life stimulus, with their departure from their former adherence to intra-community solidarity, and with their new attitude towards significantly increased personal success and income. In their homeland, Polish peasants had to make "do with less"; any manifestation of individualism was blamed in their milieu and, as a rule, suppressed by the community. Let us also note that the religious morals that prevailed in Polish community at that time were very strict, and controlled by the Roman Catholic Church, that had and still has great authority in Poland. 
The authors of this epoch research implemented a reconstruction of the whole group adaptation process and traced the strategies of developing new group identity while they were losing their previous patterns.

That fully coincides with the "romantic intention of temporality" mentioned above. The process of identification in new social coordinates and building of new group solidarity had their biographical price, measured not only by nostalgia but also by deviant behavior. The devaluation of social control of rural community was replaced by anomie and anonymous control as industrial city type, bringing about new social problems, now not only for individuals or for small groups. Therefore, the comprehension of individual / society relationship in this research brings about an institutional dimension, elevating research results to a social reform level. The hopes of social researchers and their optimism as social reformers turned critical analysis of the former Polish peasants' living conditions towards not only documentation of their experience, complicated by immigration, but also towards developing a system of socio-political and cultural measures that would provide social support to these people.

\section{MEETING POINT OF SCIENTIFIC IDEAS AND CONCEPTS}

The emergence and development of the qualitative research as a scientific movement involves not only migration issues as a field of research; it itself became an object of migration, exportation and importation of scientific thoughts, approaches and ideas, like any other sphere of scientific knowledge. This research dimension developed as migration of theoretical thought between North America and Europe before and during World War II, and also as migration and emigration of certain outstanding personalities [Inowlocki, Apitzch 2000]. In the case of qualitative-interpretative sociology, exportation and importation of scientific thought is complicated by the fact that methodologically it is usually focused on a certain locality, a certain socio-cultural context, on cultural differentiation, that brings about cultural, linguistic and methodological diversity within the entire field of qualitative-interpretative paradigm [Flick 2014]. Consequently, while analyzing the process of methodological interaction of national schools the focus of interest should be not simply the process of translation of certain scientific works and terms, but mainly the "exportation order" itself, the procedure of embedding ideas in the context of "host" environment, the interpretation of meanings in given cultural context. The global field of qualitative sociology forms in the course of such mutual enrichment/intercommunication; however, this process is different in various national contexts and often faces specific difficulties. It not only refers 
to the process of translating ideas and concepts but also to adaptation of purely methodological aspects, such as adaptation of certain methods [Flick 2014].

Such reflection as proposed here could be considered as an aspect of the sociology of science, over which Znaniecki himself pondered in the late period of his scientific activity thinking over the problem of group and individual types of attitudes towards "new" technological knowledge [Znaniecki 2013]. We are interested here in more concrete aspects: how the dominant normative model of a certain society influenced the professional attitudes and behavior towards "new" sociological thinking; how does "new" change the habitual system of knowledge and methodological orientations of scientific community. In the course of this article, we will try to trace various kinds of group and personalized reactions to "new unforeseen facts" as reaction of different roles/positions in the intellectual community [Merton 2013].

Definitely, as in any other area, the institutionalization of "the new" in science is a gradual process, which initially is seen as a revolt against the established system of thinking, as a "rebel" activity, as it was in the case of F. Znaniecki's ideas. The process can be traced in three dimensions:

1) from the perspective of the whole socio-cultural situation in the field of humanitarian knowledge in the pre- and post-perestroika Russia (e.g. the "criticism of bourgeois sociology" discourse; the attitude of scientific community towards "borrowing" Western ideas; dominance of "like-mindedness" on the state level as a single ideology and cognition methodology);

2) from the viewpoint of a professional sociological community (e.g. Russian sociology's deep-rooted orientation on Marxist ideology in the theory and on positivism in the empirical studies);

3) from the position of the internal differentiation of the professional community according to the perception of "new" and "different" ideas, which could be named as a type of personality of a "man of knowledge" (Znaniecki).

Here, it would also be appropriate to consider an additional perspective: how language barriers affect the rejection of "the new" not only from the standpoint of linguistics and difficulties with translating certain terms and texts but also as a complication for the perception and acceptance of the different culture and another logic of sociological thinking. In our analysis, we will be consistently focusing on these aspects, giving them chronological consideration: from the first references to Znaniecki's works in the 1970s-1980s until the present time. 


\section{ENTERING THE RUSSIAN SCIENTIFIC CIRCLE}

If we turn to a retrospective analysis of Znaniecki's heritage as applied to the Russian context, then the most promising focus, as we mentioned before, is to reflect on how his ideas were met and interpreted along with the change of wider socio-cultural environment during the long period of social transition from Soviet to post-Soviet period. Specifically, which aspects of his views appeared to be most critical and debatable; what ideas received response and proved to be more important for the formation and development of humanistic approach in Russian sociology.

In general, the works of Florian Znaniecki appeared in Russia's scientific discourse along with new social ideas and sociological technologies imported from the West thanks to expanding the ideological framework of social knowledge that had been strictly limited before. Although we should emphasize that even now, in "another" social time, his works cannot be referred to as the most discussed and quoted ones in Russia's modern sociological discourse. So far, not all of his works were translated into Russian, and some translations were released in abridged form. Nevertheless, most educational standards on the history of sociology contain now a section on "humanistic sociology", where the name of F. Znaniecki is associated with the ideas of Chicago School and is historically related to the North American sociology of the 1920s-40s. Conceptually, this dimension is associated with the discussion on ontological difference between naturalism and culturalism as schools of social knowledge, in the course of which F. Znaniecki's theoretical and methodological concepts on the "subject of sociology" were formed, as well as his conclusion on sociology as "a particular cultural science with its own empirical field" [Znaniecki 1996: 68], which has its own "specific" perspective as interaction between man and culture and is based on the four following "fields" of social reconstruction: social action theory, social groups theory, social role theory, and social systems theory [Znaniecki 1996].

Before describing the national and culturally specific features that existed at the time when the figure of Florian Znaniecki "entered the Russian circle", it should be noted that at different stages of his "entry" the aspects of interest depended on the overall situation in science. Therefore, the first article by F. Znaniecki in the Russian language appeared in the journal Sotsiologicheskiye Issledovaniya (Sociological Studies) in 1989. It was his purely empirical work titled: "Memoirs as an Object of Research" [Znaniecki 1989], where "biography", for the first time in Russian sociological literature, was mentioned as a possible object for analysis and interpretation of individual data. His broader theoretical 
and methodological findings published much later in an abridged translation: "Iskhodnye dannye sotsiologii" ("Initial Data for Sociology") [1996] as a translation of Chapter 3 of the book "The Method of Sociology" [Znaniecki 1934: 90-136], and "Metodologicheskiye zametki" ("Methodological Notes") [1996] as introduction to the book The Polish Peasant in Europe and America [Thomas, Znaniecki, 1918-1920]. Therefore, we can conclude that until the mid-1990s, the general methodological findings of Znaniecki were present in Russian field only as "second-hand" knowledge, narrated and interpreted by those researchers who had had the opportunity to be acquainted with English texts and had transmitted them for Russian-speaking reader with a certain degree of personal assessment.

\section{THE PERIOD OF "CRITICISM OF BOURGEOIS SOCIOLOGY" IN SOCIOLOGICAL COMMUNITY}

In this late Soviet and early post-Soviet period, from the end of the 1970s until the beginning of the 1990s, similar works were brought to light with in the framework of popular discourse on "the criticism of bourgeois sociology" [Kohn 1979, Ionin 1979]. Therefore, an important role in this specific "importation" of ideas was played by "intermediaries", who interpreted the ideas and concepts stated in the original texts. The name of Znaniecki appeared in the works of experts on the history of Western sociology, particularly American. As a result, the substance of his ideas par excellence was not discussed, but rather presented in the form of scientific information about the "other" methodological perspective existed "somewhere there" in the 1920s to the 1940s, and, as something "unknown" and "alien" to the established paradigm of Marxist-Leninist sociology and as a result had little to do with the theory and, all the more, with practice of Russia's homemade studies.

What were the stigmatizing impediments to the perception of new ideas then? Mostly, those were the dominant ideology and the established attitudes and values, including two fundamental values of "Soviet" discourse. Valentina Chesnokova, a sociologist of an older generation, describes these two values as follows, "They (that values-V.S.) are well known to those who in their time attended courses on Marxism-Leninism and Theory of Scientific Communism: (a) all people react similarly to external influence. This assumption leads to the fact that the same one influence instrument is recommended to influence all people; (b) people grow up and become adults as an outcome of being directed by external circumstances." [Chesnokova 2010]. V. Chesnokova makes a conclusion that the position of F. Znaniecki, who insisted on a differentiated approach to- 
wards subjects and their subjective nature as social actors, was regarded as alien to and inconsistent with the established values. Besides, stresses Chesnokova, profound perception of these ideas was also hindered by that typical situation for all fundamental works of world sociology: either such works did not simply exist in the Russian translation, or they were just a brief retelling of the original [Chesnokova 2010].

Thus, the "intermediaries" played the dominant role in the transmission of knowledge. One of such intermediaries, a noted Russian sociologist and an expert in history of sociology and cultural sociology, Leonid Ionin, was among the first who then started writing on the phenomenology and cultural sociology; he described his role as an "intermediary" as follows: "... I turned out to be a successful mediator, having brought some new sociological dimensions and new figures from Western sociology into domestic one. This refers to what is called interpretative sociology, social phenomenology, etc., and such figures as Schütz, Garfinkel, and others... It was the end of the 1970s when functionalism and positivism dominated in empirical studies here. ... And then it turned out to the reader that there could be a different approach to sociology." [Ionin 2007]. However, nominal acquaintance with new Western theoretical knowledge, moreover "wrapped" in the criticism of the "bourgeois" sociology was perceived either indifferently or negatively inside the community. The narrow circles only discussed these publications of theorists and that for the most part, didn't affect the sociological practitioners who continued to carry out their research according to the old patterns and under the strict control of the Communist Party organizations. [Chesnokova 2010].

\section{INTERNAL DIFFERENTIATION OF THE PROFESSIONAL COMMUNITY}

However, inside the professional community, there were the very few, whose attitudes were literally turned upside down after getting to know these new ideas. Among them was the then young Viktor Voronkov; now he is a well-known researcher who later was in charge of the Independent Social Research Center in St. Petersburg. As V. Voronkov now notes in his interview, “...I have read Leonid Ionin's works of the late 1970s (!), he wrote about the phenomenological perspective in sociology (in a genre of criticism, of course) and about interpretative sociology (it was the subject of his doctoral thesis). I was carried away by the ideas set out there. I was just amazed by how indifferently Soviet sociology, including Ionin himself, passed them by." [Voronkov 2009]. Let us 
note the last remark about the "indifference" of the sociological community; it is of substance. The scientific discourse showed that the majority received the "new" as "alien", which in no way was reflected on, or used in their practical activities. V. Voronkov tended to belong to the "marginal". However, it was he who years later became one of the pioneers and ideologists of the new socioanthropological area. This is possibly consistent with "another" role-play type of the "men of knowledge" (Znaniecki), which, in accordance with his (Znaniecki's) typology of roles played by scientists, as set out in his later work "The Social Role of the Man of Knowledge" [Znaniecki 2013:213-228], may be called a "pioneer" or a "rebel against the established systems of thinking", who is "wandering freely in search of the unexpected, who is still out of place in the environment of scientists with well-controlled traditional roles." [Znaniecki quoted by Merton 2013:210-211]. Therefore, even then Voronkov was carried away by these ideas; but at the same time, that made him a "foreign body" for the "professional leaders" [Znaniecki 2013] officially functioning in the system of sociological knowledge.

By comparing these two excerpts from the memoirs of two members of the Russian community one can conclude that the late Soviet period was the time when the first "mediated" acquaintance was made (... I became familiar with works of Leonid Ionin, Voronkov; ... I turned out to be a successful mediator, Ionin) with a different sociology (... and then it turned out that there could be a different sociology, Ionin), which was received as a violation of the traditional and generally accepted system of social thought and, therefore, only caused a reaction of indifference (...how indifferently Soviet sociology, including Ionin himself, passed them by, Voronkov). Only very few who fell in the category of "violators of traditional roles" perceived it as an impetus for something new (...I was carried away by the ideas set out there, Voronkov). The overall normative ideological order both in the country and in professional milieu hindered the acceptance of new ideas. The new logic and ideas of interpretative sociology taken as "Western-made" have remained on the level of something known, yet alien, unaccepted in the established national context.

Perhaps translation as a direct transmission of texts could and did become the only impetus for the methodological "turnaround" in the community. Such exceptions were: the only exception was the collection of translated works on the biographical method, "Biograficheski metod: istoriya, metodologiya, praktika" ("The Biographical Method: History, Methodology, Practice") [The Biographical Method 1994]. Perhaps, the meaningful stimulus for "methodological turn" was also the first research projects made in qualitative 
paradigm under the influence of the work The Polish Peasant... Among them, we could name the collective project on social mobility in three generations ${ }^{2}$. It or the first time and in full presented an agenda for biographical studies, as well as the closely related topic of the humanistic tradition in sociology and Polish contests of biographies and diaries, with references to the names of F. Znaniecki, J. Chałasiński, L. Krzywicki, B. Gołębiewski, and others. Also, as mentioned above, sometime later in 1996, abridged translations of selected works by Znaniecki and his co-author W. Thomas were published [Znaniecki 1996, Thomas, Znaniecki 1996].

\section{AMBIVALENT PERIOD OF HUMANIZATION OF SOCIAL KNOWLEDGE IN POST-SOVIET TIME}

The term "humanistic sociology" became popular in sociological discourse in the 1990s and the early 2000s; it was related to the name and works of F. Znaniecki. The interest in this term was institutionalized in sociology as a denomination to American empirical sociology that became possible due to democratization process in social life, as well as because of the changes in sociological thinking and refocusing on a discourse involving multiple paradigms. A separate section called "Humanistic sociology" appeared in textbooks, where the name of F. Znaniecki was placed along with other representatives of the Chicago School.

What is interesting here, however, are different interpretations of the very concept of "humanistic sociology", which testifies a differentiated understanding of this "exported" concept. In theoretical terms, it was discussed in the scientific articles of that time as a relationship between the "scientific truth and value" approach in social science, and more specifically, as humanistic approach towards society/individual relationship was being thought over. The researchers attempted to interpret this concept in the frames of different contexts. Some, turning to the category of values as described in F. Znaniecki's book "The Method of Sociology", emphasized the novelty of his attitude to Man as a special social value. In one of the articles devoted to The Method of Sociology the authors wrote: “...But here is a substantial addition that Znaniecki features in his work 'The Method of Sociology.' Speaking about social values, 'apart from economic, technological, religious, aesthetic and other values' he named Man himself." [Ganzha, Zotov

2 People's Destinies. Russia. XX Century. Family Biography as an Object of Sociological Study. Eds. Semenova Victoria, Foteeva Ekaterina, Daniel Bertaux. M., 1996 (Судьбы людей: Россия. ХX век. Биографии семей как объект социологического исследования. М.: Институт социологии РАН, 1996). 
2002:118]. However, further, the authors interpret this statement in a somewhat specific way.... "The need for taking into account 'the human coefficient' is explained by Polish sociologist by the fact that, unlike naturalistically understood natural facts and objects, data referring to the behaviour of people are characterized not only by facts but also by meaning, which is assigned to themselves as subjects of action, as well as by the researcher." [Ganzha, Zotov 2002:118]. It should be noted here that this is a rather inadequate understanding of the concept of F. Znaniecki's "humanistic coefficient". The essence of the difference becomes clear when we look at the quiet similar terms used by the authors while translating the notion of "humanistic coefficient". They substituted it by a similar notion of "human coefficient". Behind somewhat simplified translation stands more expansive difference in interpretation. F. Znaniecki uses it just as a methodological instrument applied to situation of researcher/respondent interaction and data interpretation, whereas the authors of this article use it as an abstract thesis on the value of individual as a social subject (taking the human factor into account). The latter meaning of this notion is typical for a strictly "Soviet" ideological discourse, which accepts the well-known notion of "human factor" as abstract verbal speculation and the need to consider "human factor" in the process of social cognition. Nevertheless, understanding of "humanistic" in Znaniecki's discourse is not abstract; it is purely situational. Howard Becker interpreted Znaniecki's position on "humanistic coefficient" as: "Znaniecki insisted on such definition of situations that are provided by the subjects participating in them, as well as on a careful analysis of their biographies as a means for establishing the nature of every definition." [Becker, Boskoff 1961].

According to another Russian sociologist, Valentina Chesnokova, the concept of "humanistic coefficient", was slowly, and not without difficulties, integrated into the minds of Russian sociologists. Reflecting on an understanding of the essence of this concept, so important to Znaniecki, she interprets it in a different way comparing with the previous interpretation: "It is not only that a researcher sees and understands the situation in which individuals involved. It appears that he should see the situation only as it is seen by them because individuals act only in accordance with what they see." [Chesnokova 2010].

Based on this concrete example of the divergence in the interpretation of the same concept of "humanism", we understand what the complicity of export and transmission of ideas from one cultural context into another is, even within one and the same national and professional community. This could create conflicts, as they belong to different thinking models or divergent "worlds of social knowledge", in Znaniecki words. In this case - the first interpretation (Ganzha, 
Zotov) is an abstract one; it fits better with the "Soviet" type of thinking on the "receiving" side. The second one of Chesnokova tends to perceive the original idea within the framework of a more general methodological approach of "exported" knowledge. More specifically, depending on the type of "man of knowledge", the cultural and conceptual type of "other" knowledge may be based on "one's own" habitually standard context or on the author's cultural context. In V. Chesnokova's work, Znaniecki's "humanistic coefficient" serves as a "new" type of knowledge, a new vision of the researcher studying social reality, which does not coincide with the standard research practices of Soviet humanitarianism. It is confirmed by the linguistic construction used by V. Chesnokova in her discourse: revealing Znaniecki's logics of reasoning, she frames it by the field of methodological logics: "should-be" formula as proposed by the author's concept (which techniques should be used from Znaniecki's point of view). The meaning of the introductory word "appear" ("it appears that the researcher should see", Chesnokova) may be interpreted as "unexpected discovery and surprise coming from what has been unexpected before". Supplemented by the "should-see" obligation construction, such a statement she understands and interprets as "new practical guide".

This different interpretation of one and the same term while transferring it from one intellectual context to another (which is rather widespread in the field of sociological knowledge while working with scientific terminology and transnational communications) proves that the new model of practical sociological thinking was mastered by the professional community in a differentiated and fragmentary way. Some researchers "overlapped" the traditional Soviet-type model of thinking and therefore, merged it into the field of traditional, habitual thinking, losing its initial "novelty" and specific features.

For F. Znaniecki as a supporter of practical knowledge, however, more important was not declared values per se, but channeling the system of values into the realm of specificity and "adapting" the ideas of humanism to situation of interaction between the researcher and the subject under study, as well as to the "social techniques" of resolving social problems. In Znaniecki's own words: "For, as an observer of cultural life can understand the data observes only if he takes it with the "humanistic coefficient", only if he does not limit his observation to his own direct experience of the data but reconstructs the experience and the men who are dealing with them actively". [Znaniecki 1986: 5]. Or, as he said in another context of cultural data: "This essential character of cultural data we call the humanistic coefficient, because such data, as the objects of the student's theoretic reflection, already belongs to somebody's else's experience and are such as this active experience makes them.'[Znaniecki 1934: 37]. Yet, it was these 
practical ideas that were accepted and used with such difficulty in a different cultural context. At the same time, "humanistic" approach was almost non-existent in the empirical practices in Russia until the early 1990s, and positivistic approach seemed to be the only possible one.

\section{"THE FIRST GREAT WORK ON METHODOLOGY IN AMERICA"}

Only in the mid-1990s, the methodological concept of the "humanistic coefficient" gave impetus to the developing of a new area in sociological studies, with various practical tactics actively developed and becoming widespread. This, however, was not occurring without internal tensions. ${ }^{3}$ Sociological practitioners actively began to employ and master Western empirical technologies, both European and American. Riding on this wave, there has been a growing interest in F. Znaniecki's methodological heritage, and his contribution is immeasurable. His co-written volume The Polish Peasant in Europe and America received the status of "the first great work on methodology in America" [Chesnokova 2010]. Due to the influence of Western colleagues ${ }^{4}$ and following the logic of studying adaptive behavior of Polish migrants within the new forms of social organization, Russian researchers turn to study the role of objective factors - such as socio-cultural transformation - in the context of their subjective interpretation. It is seen as combination of objective and subjective, whereby individuals serve

3 In the controversial article "A myth of "qualitative sociology",, published in the journal "Sotsiologicheskiye issledovaniya" (Sociological Studies) in 1994 [Batygin, Devyatko 1994], the authors strongly and emotionally opposed this new direction in the theory and methodology of empirical studies as "being an ambiguous counterpoising of the 'positivist' method of social cognition to the 'humanistic' one." Comparing qualitative sociological data with an "epistemological heap", "feminist criticism of social science" and a way to combat "male chauvinism in science", the authors arrive to a conclusion that the dispute between qualitative and quantitative methodologies is a dispute where "the participants fail to see their ridiculous misbeliefs, and the discussion itself must be banned for methodological reasons..." And a result of these contemplations they assert that "qualitative" methodology and similar non-standard methodologies that have appeared because of the connivance of the pluralists in science only beget quasi-scientific conflicts. The snowballing of these conflicts does not reflect the emergence of a new "paradigm," (in this case, this sort of reasoning is nothing more than an advertising gimmick), rather than the destruction of the social organization of scientific activity and the loss of fundamental values, on the basis of which scientific recognition is realized [Batygin, Devyatko 1994].

4 "I am getting back to these recollections just to show what the situation was in my country at the very beginning of the development of Soviet sociology, and how much the experience of the countries that had already developed research techniques meant. This underscores the importance of the methodological leap made in the United States in the 1920s-1930s, when a real revolution was taking place in this area." [Chesnokova 2010]. 
as social agents advancing innovation in accordance with their own interpretation of events. ${ }^{5}$ F. Znaniecki's dictum on the importance of a situation for analyzing social problems did come in very handy here. Such studies had opened new cognitive possibilities: they made it possible to study local, non-mass processes focusing on new innovative phenomena that do not initially acquire forms of mass behaviour, especially in the face of drastic social change. The search strategy focused on the subjective aspect: what made some individuals stick to their previous position and what made others abruptly search and try new social chance? What was the decision process? How did the decision affect their value-based consciousness?

From this empirical point of view, Russian sociologists began to consider and evaluate the significance of F. Znaniecki's basic work, co-authored by W. Thomas, The Polish Peasant in Europe and America. It was highly valued especially by empiric researchers for containing first-hand data, which could serve as a basis and model for developing one's own research strategies. "It (The Polish Peasant... - authors) contained not only initial material, i.e. letters, but their analysis in various areas as well", writes V. Chesnokova stressing its importance for practitioners. "Yet, F. Znaniecki received universal recognition not for the material, and not even for its analysis, but for his methodological introduction to the first volume. There appeared notions that were in the same rank with the most popular concepts of the $20^{\text {th }}$-century sociology: value and attitude. They stimulated countless empirical studies, were used in almost every sociological work of the 20th century, from that sociological science re-emerged rejuvenated. It has turned into an empirical science indeed." [Chesnokova 2010: 62].

\section{THE "METHODOLOGICAL MODEL" FOR USING NON-STANDARD TECHNOLOGIES}

F. Znaniecki's analysis of the migration of Polish peasants, which was culturally specific, found an eager response among Russian sociologists as a "methodological model" for using non-standard technologies and studying the harsh social transformations and new reform projects of the early to mid-1990s.

5 The studies were devoted to the emergence and development of life strategies aimed at moving into the middle class (V. Semenova, E. Rozhdestvenskaya); researching the formation of new working-class movements (K. Cleman); business strategies for regional-level female executives (A. Chirikova); and designing cultural worlds for individual ethnic communities (V. Voronkov, O. Karpenko, O. Brednikova, E. Chikadze). 
Though here migration flows from one geographical place to another were "attached" to migration flows from one social space to another ("a cultural shock situation", according to P. Sztompka). Here (in Russia) research focused on the problems of individual and group behaviour in the situation of national transition, on individual adaptation to a new institutional environment, and on building models for successful behaviour. The migration situation per se, transferred by analogy into the space of social transformations. It was considered the same due to change in the traditional normative order, where new forms of behaviour and attitudes formed under the influence of new normative order/disorder. The focus was on the search for new objective and subjective grounds, based on which new subjects were to be formed in time when new normative order has not yet gone into the public domain. These studies have resulted in constructing social typologies as different combinations of traditionally normative and innovative criteria. Hereby F. Znaniecki's approach towards disintegration and re-integration processes turned out to be quite adequate and promising [Znaniecki 1927].

As part of the consideration of transformational processes and reform activities, most important were Znaniecki's views on the formation of new normative order. Turning to this aspect, $\mathrm{V}$. Chesnokova draws on direct quotations from his works as an argumentation: "... earlier, there dominated rather simple ideas about how social norms appear. Those ideas boiled down to the fact that people, finding it difficult to coordinate their behaviour with behaviour of others, got together, thought it over, and develop a new system of rules and began to follow them. [...] As a result, social reformers give exceptional importance to changing the material environment, suggesting that in this way they influence the psyche and characters of individuals. However, it turns out that by abolishing previous laws and rules we cannot cancel definite social institutions because they are deeply rooted in people's minds on level of values, Znaniecki believes. "Not only attitudes, but also values fixed by tradition and conditioning the attitudes cooperate with the production of final effect quite independently, and often despite the intentions of social reformers." [Thomas, Znaniecki 1927: 51]. The newly created social organization includes a project conceived by the reformers plus as an addition the previous values. [...] If the Bolsheviks had not rejected so contemptuously the "fictions" of bourgeois "pseudoscientists", they could have read in the work by Thomas and Znaniecki (published in 1918) the lines, as if specially addressed to them: "At every step we try to produce certain social values without taking into account the values which are already there and upon which the result of our efforts will depend as much as upon our intention and persistence." [Thomas, Znaniecki 
1927: 52]. Yet, our reformers seem to have remained in the $19^{\text {th }}$ century " $[\ldots]$ We need to learn how to evoke the desired attitudes in the mind of an individual, and for that we need to know what attitudes are already in his/her mind, and whether among them there are those who will necessarily respond to the incentives that society can apply to them." [Chesnokova 2010:74].

\section{THE PERIOD OF INSTITUTIONALIZATION OF QUALITATIVE RESEARCH IN RUSSIA}

Since the mid-1990s, there has appeared a whole new generation of researchers, who have practically become the "aborigines" in qualitative methodology, considering it as an independent segment of professional activity and identifying themselves with this area. The educational standard includes qualitative methodology as a component, and people are free to choose their identity as "qualitative" or "quantitative" sociologists. Unlike the identity of a "quantitative", that of a "qualitative" is described by one of the supporters of the last, Victor Voronkov, who was mentioned above, “... the gap between the proponents of quantitative method and constructivists is bottomless. These are different sciences within 'sociology' in a broad sense, which encompasses all social sciences. My science is studying the rules by which people act. And I do not see a way to understand the innumerable diversity of these rules in a multitude of social environments other than through close communication with people via participating observation and - if absolutely involuntary - through interviews." [Voronkov 2009]. Let us note that V. Voronkov's methodological stance is even more radical on the qualitative-quantitative scale, because he is rather skeptical about life documents, such as diaries, autobiographies, biographies, or qualitative interview data, opting for participating observation to approach social interactions as closely as possible. At present, the institutionalization of qualitative research and even its internal segmentation into separate techniques and areas (biographical research, social ethnography, case studies, and mix methods) has happened in Russia, albeit not immediately, but in the course of a rigid confrontation and clearcut delineation between the two research ideologies. This institutionalization was much facilitated by the arguments set forth by F. Znaniecki, specifically regarding his understanding of analytical induction.

Naturally, today's interest in F. Znaniecki's works focused mostly on the more complicated aspects of his methodological position. Mainly on initial data analysis principles and, first and foremost, on the discussion of his 
analytical induction strategy, systematization and classification principles that are included in all humanistic sociology textbooks, serving as a guide to practical sociologists. Such material, mostly educational, aimed at describing the entire course of a research project starting from the choice of personal information until the strategy for field research and data analysis, using the research tactics of W. Thomas and F. Znaniecki described in The Polish Peasant in Europe and America [Devyatko 2009; Semenova 2009; Rozhdestvenskaya 2012]. As an example, let us quote the field survey recommendations given in a work by V. Chesnokova. "The accumulated mistrust of theories, of pure "speculation" did not allow the "inductivists" to correctly apply the available theoretical constructions ... F. Znaniecki's work "The Method of Sociology", published in 1934, has played a major role in overcoming this crisis. Without rejecting the method of induction as a useful research technique, he proposed to move from pure induction to analytic induction. Instead of simply enumerating facts and calculating probabilities based on correlation, the abstraction method is used. In accordance with this method, the characteristic features of a single specific case, which are significant for a particular study in question, are abstracted from the case." [Chesnokova 2010:85]. In this regard, the most important for future researchers, especially young ones, is to consider the logics used in creating constructive typologies, proposed by Znaniecki. For example, V. Chesnokova herself used Znaniecki's methodology for creating her own typology of Russian characters ("a typology of Russian archetypes", [Kasjanova-Chesnokova 2003]. She used different elements of Znaniecki typology building technique (abstraction level, situation elements, personality elements, as well as social circles and explanatory constructions), and discussed the possible limitations and the degree of validity of the typology she obtained. "Let us make it clear, however, that Znaniecki was not actually conducting an empirical study per se; he was creating a sort of a project for future empirical studies. Therefore, his explanatory constructions and generalizations are no more than just hypotheses. They are based on his social experience of a researcher, which he, equipped with scientific methodological and theoretical skills, turns into preliminary guestimates." [Chesnokova 2010:96].

Over time, F. Znaniecki's analytical induction method was further developed in the Russian practice of qualitative research, but that was mostly associated with the name of Ch. Pierce. Therefore, the combination of analytical induction with Ch. Pierce's notion of abduction as a way of putting forward hypotheses has grown into a system for analysing qualitative data, in which practically all types of analytical logic appear to be in demand at different stages and for various 
problems. Using the abduction method, a sociologist can put forward a certain number of competing explanatory hypotheses. While quantitative induction can determine the probability of findings to occur, analytical induction aims at typology construction.

\section{CONCLUSION}

In time, Russia developed its own methodological basis and its own textbooks on qualitative methods [Semenova 1998, Semenova 2009, Rozhdestvenskaya 2009, Gotlib 2002] as well as its own periodicals (journals "INTER" and "Laboratorium"). Nevertheless, at the beginning, the qualitative and interpretative approaches borrowed from Western Europe and America where Znaniecki's ideas for bringing about social transformation had been embraced.

Belatedly and not without difficulties, W. Thomas and F. Znaniecki heritage found its way into the context of Russian sociology. The reception of ideas of F. Znaniecki in the Russian sociological context took place in several stages, thanks both to the transformation of Russian society as well as changes in social science itself. Initially, it came in only as new information, as some "other's knowledge and language, unusual and little applicable in another context. The next stage marks active translation and integration of the works of F. Znaniecki in the corpus of classical sociological knowledge and understanding of the contribution of the Polish school of qualitative analysis in the emerging area of qualitative sociology in Russia. Only in time, it has become public domain, mainly in two areas of social knowledge. In the area of theoretical knowledge, F. Znaniecki's name has become significant as the part of world sociology history as one of the dimensions of social reformist tradition of Chicago School [Ionin 2004]. This stage is also marked by methodological discussions on the key points of social analysis, for example, the discussion on the qualitative and quantitative approach and possibilities of new methodology. These discussions bore the traces suggested by F. Znaniecki methodology of empirical studies, which operationalized the theory of attitudes-values for the analysis of personal documents, as well as rehabilitated the subjectivity of the respondents for the purposes of sociological research, described empirical access to communities and theorizing subcultures. For sociological practitioners, his legacy is used as an example of empirical orientation of sociological school, which makes it possible to collect social information that has not only applied practical value but theoretical value as well [Barazgova 1997]. For qualitative studies with their emphasis on the active voice of the actor proved to be heuristic ideas of F. Znaniecki about the relationship between structure and agency, which is 
closely related to the problem of micro-macro. Attitude is associated with agency, and value is associated with structure. In this sense, F. Znaniecki conceptualized key issues of social theory and worked ahead of his time.

\section{BIBLIOGRAPHY}

Abels Heinz. 1998. "Romantics, phenomenological sociology and qualitative social research". Journal of Sociology and Social Anthropology 1: 114-138.

Barazgova Evgenia. 1997. William Thomas \& Florian Znaniecki: Chicago school methodological orientation. In: American sociology (tradition and modernity). Textbook, E. Barazgova (ed.), 50-63. Ekaterinburg: Delovaya kniga.

Batygin Gennady, Devyatko Inna. 1994. "A myth of "qualitative sociology". Sociologicheskie Issledovania 2: 28-42.

Becker Howard. 1961. Modern sacral and secular theory. In: Modern sociological theory in continuity and change, $\mathrm{H}$. Becker, A. Boskoff (eds.), 324-336. Moscow: Inostrannaya literatura.

Chesnokova Valentina. 2010. FlorianZnaniecki. Cultural science. The method of personal documents. In: The sociological language. Lecture course. http://polit.ru/article/ 2008/11/18/chesn/ [access: 14.12. 2017].

Deviyatko Inna. 2009. Research method in sociology. Textbook. Ekaterinburg: UrGY.

Flick Uwe. 2014. "Challenges for qualitative inquiry as a global endeavor: introduction to the special issue". Qualitative Inquiry 20(9): 1059-1063. http://journals.sagepub. com/toc/qixa/20/9 [access 05.03.2018].

Ganzha Anna, Zotov Andrey. 2002. "Florian Znaniecki's humanistic sociology". Sociologicheskie Issledovanya 3: 112-120.

Gotlib Anna. 2002. Introduction to sociological research: qualitative and quantitative approach. Samara: Samarski Universitet.

Inowlocki Lena, Ursula Apitzsch. 2000. Biographical analysis: German school? In: The turn to biographical methods in social science. P. Chamberlayne, J. Bornat, T. Wengraf (eds.), 53-71. London: Routledge.

Ionin Leonid. 1979. Understanding sociology. Historical and critical analysis. Moscow: Nauka.

Ionin Leonid. 2004. Philosophy and methodology of empirical sociology. Moscow: Izdatelski dom GU VZHE.

Ionin Leonid. 2007. "We have to agree with our choice". Teleskope 3: 2-14.

Kasjanova Kcenya (Chesnokova Valentina). 2003. On Russian national character. Moscow: Akademichesky project.

Kohn Igor (ed.) 1979. The history of bourgeois sociology from early X1X till early XX century. Moscow: Nauka. 
Merton Robert. 1973. Znaniecki's social role of the man of knowledge. In: The sociology of science. Theoretical and empirical investigations. N. Storer (ed.), 41-47. Chicago: Chicago University Press.

Mescherkina Elena, Semenova Victoria. (eds.). 1994. Biographical method: history, methodology, practices. Moscow: Institute Sociologii RAN.

Rozhdestvenskaya Elena. 2012. Biographical method in sociology. Moscow: Izdatelski Dom GU VSHE.

Semenova Victoria, Foteeva Ekaterina, Bertaux Daniel (eds.). 1996. People's destinies. Russia. XX century. Family biography as an object of sociological study. Moscow: Institute of Sociology.

Semenova Victoria. 1998. Qualitative methods: Introduction to humanistic sociology. Moscow: Dobrosvet.

Semenova Victoria. 2009. Qualitative methods in sociology. In: The Strategy in sociological research. V. Yadov (ed.), 346-408. Moscow: Omega-L.

Thomas William, Znaniecki Florian. 1927. The Polish peasant in Europe and America. New-York: Alfred Knopf.

Voronkov Victor. 2009. "On politicization of social science”. Zhurnalnyi Zal 1(63). http://magazines.russ.ru/nz/2009/1/vv3.html\#_ftn1 [access: 01.01.2018].

Znaniecki Florian. 1934. The method of sociology. New-York: Farrar \& Rinehart.

Znaniecki Florian. 1986. The social role of the man of knowledge. New Brunswick: Transaction books.

Znaniecki Florian. 1989. "Memoirs as an object of research". Sociologicheskie Issledovaniya 1: 106-10.

Znaniecki Florian. 1996. Initial data in sociology. In: American sociological thought: Texts. V. Dobrenkov (ed.), 60-76. Moscow: Izdatelstvo Mezhdunarodnogo Universiteta Biznesa i Upravlenia.

Victoria Semenova

Elena Rozhdestvenskaya

\section{DZIEDZICTWO FLORIANA ZNANIECKIEGO \\ W KONTEKŚCIE DYSKURSU ROSYJSKIEGO}

Streszczenie

Artykuł poświęcony jest problemowi eksportu-importu wiedzy naukowej w kontekście globalizacji paradygmatu jakościowego. Dotyczy on nie tylko barier językowych, ale także kontekstów politycznych i naukowych, w których osadzone są badania [Flick 2014]. W artykule, starając się poruszyć niektóre aspekty tego procesu, koncentrujemy się na specyfice rosyjskiej w przyjmowaniu oraz interpretowaniu idei i koncepcji F. Znanieckiego. 1) W jaki sposób dominujący normatywny model społeczeństwa wpłynął na postawy zawodowe i zachowanie wobec „nowego” sposobu myślenia socjologicznego? 2) Jak kształtowały się wzajemne oddziaływania między „nowym” 
i „starym” systemem wiedzy i metodologicznymi orientacjami środowiska naukowego? 3) Jak wewnętrzne zróżnicowanie środowiska naukowego (w szczególności typ „uczonego”) wpłynęło na postrzeganie nowych idei? W artykule próbujemy śledzić ten proces $\mathrm{w}$ sposób chronologiczny w ramach zmieniającego się kontekstu społecznego i zawodowego kraju. Pierwsza część poświęcona jest późnemu okresowi sowieckiemu; druga - pierwszemu okresowi postradzieckiej demokratyzacji i humanizacji w dziedzinie wiedzy społecznej, a ostatnia - obecnej sytuacji rozwoju specyfiki narodowej opartej na początkowym imporcie metodologicznego pojęcia „współczynnika humanistycznego" (F. Znaniecki) wraz z szerokim przepływem europejskiej i amerykańskiej tradycji jakościowo-interpretacyjnej.

Słowa kluczowe: Florian Znaniecki, globalizacja wiedzy, socjologia interpretacyjna, zawodowa społeczność socjologiczna, badania empiryczne, kontekst rosyjski. 